\title{
Validasi Kriteria Diagnosis Infeksi Saluran Kemih Berdasarkan American Academy of Pediatrics 2011 pada Anak Usia 2-24 Bulan
}

Ikhsan Trinadi, Eggi Arguni, Kristia Hermawan

Departemen Ilmu Kesehatan Anak Fakultas Kedokteran Universitas Gadjah Mada, Yogyakarta

Latar belakang. Gejala klinis infeksi saluran kemih (ISK) pada anak yang tidak spesifik dapat menyebabkan keterlambatan diagnosis. Keterlambatan penanganan berkaitan dengan risiko terbentuknya parut ginjal. Tahun 2011 American Academy of Pediatrics (AAP) mengeluarkan panduan klinis diagnosis ISK anak usia 2-24 bulan dengan akurasi yang baik. Penggunaan lokal kriteria ini belum divalidasi.

Tujuan. Validasi kriteria diagnosis ISK AAP 2011 pada anak usia 2-24 bulan di RSUP Dr Sardjito, Yogyakarta.

Metode. Penelitian cross sectional periode Januari 2013 hingga Juni 2015 dilakukan terhadap anak usia 2-24 bulan dengan demam yang memiliki data urinalisis dan kultur urin. Hasil penilaian kriteria AAP dibandingkan dengan pemeriksaan kultur urin.

Hasil. Berdasarkan hasil kultur didapatkan 21 pasien menderita ISK, sementara 64 pasien di diagnosis diare akut, demam dengue, pneumonia, dan infeksi CMV. Didapatkan sensitifitas, spesifisitas, rasio kemungkinan positif, rasio kemungkinan negatif kriteria diagnosis AAP 2011 adalah 85,7\%, 92,2\%, 11,0, dan 0,2.

Kesimpulan. Kriteria AAP 2011 bisa digunakan sebagai alat diagnostik yang reliable untuk memprediksi ISK pada anak.

Sari Pediatri 2016;18(1):17-20

Kata kunci: infeksi saluran kemih, kriteria diagnosis AAP 2011, demam, anak usia 2-24 bulan

\section{Validation of 2011 American Academy of Pediatrics Criteria for Diagnosis of Urinary Tract Infection in Children Aged 2-24 Months}

Ikhsan Trinadi, Eggi Arguni, Kristia Hermawan

Background. Untreated urinary tract infection (UTI) may lead to permanent renal injury. Hence, nonspecific clinical signs in infant may mislead diagnosis and treatment. In 2011 American Academy of Pediatrics (AAP) released a revision of the 1999 Clinical Practice Guideline for UTI in young children with age 2 to 24 months of age. Up to date use of this guidelines has not been validated in our setting.

Objective. To validate the 2011 AAP diagnostic criteria for UTI in children aged 2-24 months in Dr. Sardjito Hospital, Yogyakarta. Methods. We conducted cross sectional study by tracking medical records of children aged 2-24 months, with fever who visited our hospital. Eligibility criteria were complete medical record regarding grade and duration of fever, urinalysis results, urine culture and other confirmatory diagnostic tests to support the diagnosis other than UTI. AAP criteria were used to assess whether the patient had UTI, then the results were compared with final diagnosis based on urine culture or other confirmatory diagnostic tests.

Result. From January 2013 to June 2015, we screened 114 patients with febrile episodes. Out of these numbers, only 85 febrile episodes with complete data, 21 patients had UTI, while 64 patients were diagnosed as acute watery diarrhea, dengue fever, pneumonia, and CMV infection.

Sensitivity, specificity, LR+, LR- of AAP diagnostic criteria were 85,7\%, 92,2\%, 11,0\% and 0,2\% respectively.

Conclusion. 2011 AAP criteria can be used as a reliable diagnostic tool for defining UTI in children. Sari Pediatri 2016;18(1):17-20

Keywords: urinary tract infection; 2011 AAP diagnostic criteria; fever, children 2-24 month

Alamat korespondensi: Dr. Ikhsan Trinadi, Dr. Eggy Arguni, PhD, Sp.A, Dr. Kristia Hermawan, Sp.A. Fakultas Kedokteran Universitas Gadjah Mada, RSUP Dr Sardjito. Popongan No. 256c, RT 13 RW 30 Sinduadi, Mlati, Sleman, Yogyakarta. E-mail: slimshade13@gmail.com 
I nfeksi saluran kemih (ISK) merupakan infeksi serius yang paling sering terjadi pada awal kehidupan. Jika tidak ditangani dengan baik, ISK dapat menyebabkan komplikasi, seperti hipertensi, proteinuria, pielonefritis, parut ginjal dan end state renal disease. Pada kelompok anak usia muda gejala ISK tidak spesifik sehingga dapat menyebabkan keterlambatan diagnosis dan terapi. ${ }^{1-7}$

Tahun 2011, American Academy of Pediatrics (AAP) melakukan revisi pedoman untuk diagnosis dan manajemen ISK pada anak usia 2-24 bulan. Pedoman ini ditujukan untuk membantu klinisi dalam menangani ISK, menentukan pemeriksaan urinalisis, dan terapi pada anak di poliklinik dan ruang gawat darurat. ${ }^{8,9}$

Penerapan pedoman AAP 2011 di tempat kita yang merupakan wilayah tropis mempunyai masalah perbedaan karakteristik pasien dan penyakit penyebab demam lainnya. Penyebab demam lain pada kelompok usia 2-24 bulan cukup bervariasi, antara lain, diare cair akut, infeksi saluran pernafasan akut, infeksi dengue, malaria dan meningitis. ${ }^{10-12}$ Penelitian ini bertujuan untuk mengevaluasi presisi kriteria diagnosis ISK menurut AAP 2011 di RSUP Dr Sardjito, Yogyakarta.

\section{Metode}

Penelitian cross sectional dengan data rekam medis pasien anak usia 2-24 bulan dengan demam yang datang ke RSUP Dr. Sardjito, baik rawat jalan maupun rawat inap. Penelitian dilakukan di RSUP Dr. Sardjito, Yogyakarta. Data diambil dari Januari 2013 hingga Juni 2015. Pengambilan dan analisis data dilakukan bulan Mei 2015 hingga Juni 2015.

Dilibatkan anak usia 2-24 bulan yang datang ke RSUP Dr. Sardjito, dengan demam atau gejala sugestif ISK pada Januari 2013 hingga Juni 2015. Pasien dieksklusi bila tidak memiliki data lengkap, kondisi klinis sesuai dengan kriteria AAP, data urinalisis dan kultur urin atau pemeriksaan penunjang lain sebagai baku emas diagnosis apabila pasien didiagnosis selain ISK.

Infeksi saluran kemih ditegakkan berdasarkan hasil kultur urin positif dengan bakteriuria signifikan, jumlah kuman $>50.000 /$ colony forming unit. Berdasarkan kriteria AAP 2011, kelompok risiko ISK anak perempuan adalah kulit putih, usia $<12$ bulan, suhu $>2$ hari, demam $>2$ hari, dan tidak ada sumber infeksi lain. Kemungkinan ISK anak perempuan adalah $<1 \%$ berisiko tidak lebih dari 1 dan $<2 \%$ berisiko tidak lebih dari 2. Sementara itu, pada anak laki-laki kelompok risiko ISK adalah kulit putih, usia $<12$ bulan, suhu $>39$, demam $>2$ hari, dan tidak ada sumber infeksi lain. Kemungkinan ISK $<1 \%$ dengan faktor risiko tidak disirkumsisi A dan sirkumsisi tidak lebih dari 2, sedangkan $<2 \%$ tidak ada risiko tidak disirkumsisi dan sirkumsisi tidak lebih dari 3. Data dianalisis dengan menghitung sensitivitas, spesifisitas, nilai prediksi positif, dan nilai prediksi negatif.

\section{Hasil}

Didapatkan 114 data kunjungan anak usia 2-24 bulan dengan keluhan demam di instalasi rawat jalan dan rawat inap. Delapanpuluh lima pasien yang memenuhi kriteria inklusi dan eksklusi dimasukkan dalam kriteria AAP dan dianalisis.Karakteristik dasar subyek penelitian tertera pada Tabel 1 .

Tabel 1. Karakteristik dasar subyek penelitian

\begin{tabular}{lc}
\hline Karakteristik & Nilai \\
\hline Umur, bulan, rerata, SD & $11,02(6,122)$ \\
Minimal & 2 \\
Maksimal & 24 \\
Jenis kelamin, n (\%) & \\
Laki-laki & $52(61)$ \\
$\quad$ Perempuan & $33(38,8)$ \\
Warna kulit, n (\%) & \\
$\quad$ Putih & $85(100)$ \\
Hitam & $0(0)$ \\
Sirkumsisi, n (\%) & \\
Ya & $1(1,9)$ \\
Tidak & $84(98,1)$ \\
Kelainan anatomis, n (\%) & \\
$\quad$ Ya & $8(9,4)$ \\
Tidak & $77(90,6)$ \\
Lama demam, (hari) & 1 \\
Minimal & 120 \\
Maksimal & \\
\hline
\end{tabular}

Perhitungan nilai diagnostik tertera pada Tabel 2.

Didapatkan sensitifitas, spesifisitas, nilai duga positif, nilai duga negatif, rasio kemungkinan positif, 
Tabel 2. Nilai diagnostik ISK berdasarkan kriteria AAP

\begin{tabular}{llccc}
\hline & & \multicolumn{2}{c}{ ISK kultur urin } & Total \\
\cline { 3 - 5 } & & Positif & Negatif & \\
\hline Kriteria APP & Positif & 18 & 5 & 23 \\
& Negatif & 3 & 59 & 62 \\
Total & & 21 & 64 & 85 \\
\hline
\end{tabular}

rasio kemungkinan negatif kriteria diagnosis AAP berturut-turut adalah $85,7 \%, 92,2 \%, 78,3 \%, 95,2 \%$, $11,0 \%$, dan $0,2 \%$.

\section{Pembahasan}

Hasil penelitian oleh Gorelick ${ }^{13}$ menunjukkan kriteria klinis risiko ISK AAP 2011 mempunyai sensitivitas $88 \%$ dan spesifisitas 30\% untuk memprediksi kejadian ISK. ${ }^{13}$ Pemeriksaan urinalisis mempunyai sensitivitas, spesifisitas leukosit esterase 83\%, 78\%, nitrit 53\%, $98 \%$, mikroskopis, sel darah putih $73 \%, 81 \%$, bakteria $81 \%, 83 \%$. Hal tersebut menunjukkan bahwa kriteria AAP dengan menggunakan kriteria klinis risiko kemungkinan ISK dan hasil urinalisis (pyuria atau bakteriuria) mempunyai akurasi yang lebih baik dibandingkan dengan pemeriksaan urinalisis saja.

Kriteria ini dapat digunakan untuk memprediksi kejadian ISK, tetapi tidak bisa menggantikan kultur urin sebagai baku emas diagnosis ISK. Hasil kultur urin digunakan untuk menentukan langkah selanjutnya. Apabila didapatkan hasil kultur urin negatif, terapi antibiotik dihentikan. Apabila didapatkan hasil positif, terapi antibiotik disesuaikan dengan hasil sensitivitas. Pada setting lokal, penegakan diagnosis ISK dengan urinalisis tanpa pemeriksaan kultur urin sudah tidak relevan lagi.

Penerapan kriteria AAP pada setting klinis sangat membantu klinisi. Berdasarkan penerapan kriteria AAP, klinisi dapat membuat keputusan klinis kapan dilakukan pemeriksaan urinalisis pada anak usia 2-24 bulan dengan demam tanpa sumber infeksi yang jelas, menegakkan diagnosis ISK pada anak usia 2-24 bulan, dan mencegah keterlambatan terapi karena menunggu hasil kultur urin.

Pada kelompok Gram negatif, bakteri patogen yang sering menyebabkan ISK adalah E coli, Klebsiella, dan Proteus. Sebaliknya, pada kelompok Gram positif, bakteri pathogen penyebab ISK adalah Streptokokus beta hemolitikus grup B, Enterokokus sp, dan Stafilokokus aureus. ${ }^{7}$ Tata laksana mikrobakterial penyebab ISK tersebut membutuhkan terapi antibiotik, jika tidak ditangani dengan baik dapat menyebabkan komplikasi, seperti hipertensi, proteinuria, pielonefritis, parut ginjal dan gagal ginjal terminal. ${ }^{1-7}$ Penggunaan antibiotik yang tidak rasional dapat meningkatkan resistensi antibiotik, risiko toksisitas obat, juga biaya terapi karena menggunakan antibiotik lini kedua. Prevalensi resistensi antibiotik pada ISK anak meningkat terlihat pada tingginya resistensi uropatogen. Hal tersebut disebabkan pemeriksaan urinalisis saat pemberian antibiotik tidak dilakukan, penggunaan antibiotik yang tidak selektif, dan pemilihan antibiotik empirik yang tidak tepat. Penggunaan antibiotik pada ISK anak masih sering overuse dan tidak rasional. ${ }^{14}$

Kriteria diagnosis AAP mempunyai akurasi yang baik. Dengan menggunakan kriteria AAP, kemungkinan kesalahan tidak mengobati pasien yang terbukti ISK dengan hasil kultur urin positif sekitar 14,3\% dan kemungkinan mengobati pasien yang tidak terbukti ISK dengan menggunakan kultur urin sekitar 7,8\%. Penggunaan kriteria AAP 2011 sebagai pedoman untuk memberikan antibiotik pada pasien akan meningkatkan penggunaan antibiotik yang rasional.

Tidak semua spektrum pasien anak usia 2-24 bulan dengan klinis ISK yang datang selama periode penelitian bisa dilibatkan karena tidak semua pasien diperiksa urinalisis dan kultur urin pada saat yang bersamaan. Kualitas dan cara pengambilan sampel urin terkait dengan lamanya penundaan pemeriksaan sejak sampel urin diambil juga tidak bisa dikontrol. Hal tersebut bisa diperbaiki dengan melakukan penelitian secara prospektif.

\section{Kesimpulan}

Kriteria diagnostik AAP untuk ISK pada anak usia 2-24 bulan mempunyai nilai diagnostik yang baik, dan reliable untuk digunakan sebagai alat diagnostik di RSUP Dr. Sardjito. 


\section{Daftar pustaka}

1. Shaikh N, Morone NE, Lopez J. Does this child have a urinary tract infection? JAMA 2007;298:2895-904

2. Winter AL, Hardy BE, Alton DJ, Arbus GS, Churchill BM. Acquired renal scars in children. J Urol 1983;129:1190-4.

3. Smellie JM, Poulton A, Prescod NP. Retrospective study of children with renal scarring associated with reflux and urinary infection. BMJ 1994;308:1193-6.

4. Nickavar A, Sotoudeh K. Treatment and prophylaxis in pediatric urinary tract infection. Int J Prev Med 2011;2:4-9.

5. Haris S, Sarindah A, Yusni, Raihan. Kejadian infeksi saluran kemih di ruang rawat inap anak RSUD Dr.Zainal Abidin Banda Aceh. Sari Pediatri 2012;14:235-40.

6. Fisher DJ. Pediatric urinary tract infection. Diakses pada 24 April 2016. Didapat dari: http://emedicine.medscape. com/article/969643.

7. Zorc JJ, Kiddoo DA, Shaw KN. Diagnosis and management of pediatric urinary tract infections. Clin Microbiol Rev 2005;18:417-22.

8. Subcommittee on Urinary Tract Infection, Steering
Committee on Quality Improvement and Management, American American Academy of Pediatric. Urinary tract infection. Clinical practice guideline for diagnosis and management of the initial UTI in febrile infants and children 2 to 24 month. Pediatrics 2011;128:595-610.

9. Finnell SM, Carroll AE, Downs SM. Technical report: diagnosis and management of an initial urinary tract infection in febrile infants and young children. Pediatrics 2011;128:749-70.

10. Montini G, Tullus K, Hewitt I. Febrile urinary tract infection in children. N Engl J Med 2011;365:239-50.

11. Pujiarto PS. Demam pada anak. Maj Kedokt Indonesia 2008;58:346-52.

12. Gupta I, Guin P. Communicable diseases in the SouthEast Asia region of the World Health Organization: towards a more effective response. Bull WHO 2010; 88:199-205.

13. Gorelick MH, Hoberman A, Kearney D, Wald E, Shaw KN. Validation of a decision rule identifying febrile young girls at high risk for urinary tract infection. Pediatr Emerg Care 2003;19:162-64.

14. Edlin RS, Copp HL. Antibiotic resistance in pediatric urology. Ther Adv Urol 2014;6:54-61. 